\title{
Analisis Faktor Penghambat dan Pendukung Pendayagunaan Tanaman Gonda sebagai Produk Wisata Kuliner Khas Desa Bongan
}

\author{
I Gusti Ayu Ari Agustini \\ Program Studi DIII Seni Kuliner, Politeknik Internasional Bali, Tabanan, Indonesia \\ Email: igari0908@gmail.com
}

\begin{abstract}
This study aimed at finding out the supporting and hampering factors in utilizing Gonda plant as the culinary product of Bongan Village. This research was a descriptive qualitative research and using observation, interviews, and literature study to collect the data. It was done in Bongan village. Based on the results of analysis, the supporting factors are Gonda plants are unseasonal plants that can be harvested many times in a year, there is strong determination and commitment, and the support of the Ministry of Tourism and Creative Economy in collaboration with Politeknik Internasional Bali. Meanwhile the hampering factors are the the limited numbers of people utilizing Gonda, the limited ability to see the business opportunities, the lack of ability and willingness, the chips and gonda tea need to be improved, the packaging is still simple, the cleanliness of the production area, and there is no scientific test results of Gonda plants.
\end{abstract}

Keywords: Culinary Tourism, Supporting Factor, Hampering Factor, Gonda Utilization

\begin{abstract}
Abstrak
Penelitian ini bertujuan untuk menganalisis dan mengkaji factor penghambat dan pendukung pendayagunaan tanaman Gonda sebagai produk wisata kuliner khas Desa Bongan. Penelitian ini merupakan penelitian deskriptif kualitatif. Data dikumpulkan melalui observasi, wawancara, dan studi dokumentasi. Penelitian dilakukan di Desa Wisata Bongan dan melibatkan masyarakat Bongan. Hasil analisis menunjukkan bahwa factor penghambat pendayagunaan tanaman Gonda adalah jumlah masyarakat yang memberdayakan tanaman Gonda masih terbatas, keterbatasan kemampuan melihat peluang usaha, kemampuan dan kemauan yang masih rendah, hasil produksi keripik dan teh gonda masih perlu disempurnakan, kemasan yang masih sederhana, penataan ulang serta kebersihan dan kerapian area produksi, serta belum memiliki hasil uji lab yang resmi. Sedangkan factor pendukung pendayagunaan tanaman Gonda antara lain melimpahnya hasil panen tanaman gonda yang tidak mengenal musim, adanya tekad dan komitmen yang kuat, dan adanya peran serta pemerintah pusat dalam hal ini Kemenparekraf bekerjasama dengan institusi pendidikan, salah satu institusi yang berperan yaitu Kampus Politeknik Internasional Bali.
\end{abstract}

Kata kunci: Wisata Kuliner, Faktor Penghambat, Faktor Pendukung, Pendayagunaan Gonda 


\section{PENDAHULUAN}

Bali merupakan salah satu destinasi pariwisata terbesar di dunia. Ratusan ribu wisatawan, baik wisatawan mancanegara maupun domestic datang berkunjung ke Bali tiap tahunnya. Sektor pariwisata menjadi salah satu tulang punggu perekonomian masyarakat Bali. Terlepas dari hiruk pikuk dan gemerlap dunia pariwisata, Bali juga merupakan pulau agraris. Menurut Badan Pusat Statistik Provinsi Bali (2018), terdapat 477.439 petani di Bali.

Desa Bongan yang terletak di Kabupaten Tabanan, Provinsi Bali merupakan salah satu desa di Bali yang masih mengandalkan kegiatan pertanian sebagai mata pencaharian warganya. Hal ini dikarenakan Desa Bongan memiliki lahan pertanian yang luas. Desa Bongan memiliki luas lahan pertanian 208 hektar dari total 445 hektar luas wilayah desa. Hasil pertanian utama Desa Bongan yaitu padi dan tanaman gonda. Melimpahnya tanaman gonda membuat masyarakat berkeinginan untuk dapat melakukan pengolahan lebih lanjut sehingga tanaman gonda yang dihasilkan dapat memiliki nilai guna sekaligus nilai tambah. Masyarakat secara perseorangan maupun berkelompok telah melakukan upaya dalam meningkatkan manfaat dari tanaman gonda yang dimiliki Desa Bongan, dengan harapan Desa Bongan nantinya akan memiliki produk kuliner khas Bongan sebagi pelengkap produk wisata yang ada. Namun kenyataannya, hanya beberapa orang saja yang melakukan pengolahan tanaman gonda menjadi produk kuliner, selebihnya tanaman gonda dijual seadanya sebagai hidangan sayur.

Tanaman gonda yang tidak mengenal musim ini, hampir selalu ada dalam jumlah melimpah dikarenakan masa panennya cukup singkat yaitu empat minggu. Jumlah yang melimpah tidak berarti masyarakat mempunyai penghasilan yang baik dari tiap kali hasil panennya, ini dikarenakan masa ketahanan tanaman gonda setelah panen cukup singkat, maksimal 24 jam. Setelah itu tanaman gonda akan layu dan mulai rontok serta mengalami perubahan warna pada batang dan daunnya. Hal ini yang menyebabkan masyarakat tidak begitu antusias dalam tiap kali masa panennya, hanya sebatas melakukan kegiatan tanam, panen dan menjual seadanya saja. Hal ini tidak hanya terjadi di Desa Bongan, Taib dan Rowsita (2018) mengatakan bahwa komoditi pertanian di Indonesia belum dikelola dan dikembangkan secara optimal oleh masyarakat. Masyarakat cenderung menjual komoditi tersebut dalam bentuk segar sehingga tidak mampu memberikan nilai tambah bagi petani. Inovasi dan kreatifitas masyarakat dalam mengelola dan mengolah hasil pertanian sangat diperlukan sehingga memberikan nilai tambah bagi komoditas dan petani.

Di tengah melimpahnya panen tanaman Gonda, beberapa warga Desa Bongan berinovasi mengolah tanaman Gonda menjadi olahan the. Namun hingga saat ini, the Gonda tersebut masih dikonsumsi pribadi dan belum dikomersilkan. Melihat hal tersebut, tanaman Gonda memiliki potensi untuk menjadi olahan atau produk wisata kuliner khas Desa Bongan. Desa Bongan Diketahui bahwa Desa Bongan telah ditetapkan sebagai Desa Wisata secara resmi pada tanggal 06 November 2018 dengan Surat Keputusan Bupati Tabanan Nomor 180/ 457/ 03/HK \& HAM/ 2018.

Dalam usaha mengembangkan atau mandayagunakan tanaman Gonda sebagai produk wisata kuliner khas Desa Bongan, penting dilakukan kajian untuk mengetahu factor penghambat dan pendukung yang akan mempengaruhi kesuksesan dalam mendayagunakan tanaman Gonda sebagai produk wisata kuliner khas Desa Bongan. Penelitian ini bertujuan untuk menganalisis factor penghambat dan pendukung pendayagunaan atau pengolahan tanaman Gonda menjadi 
produk wisata kuliner khas Desa Bongan sehingga strategi pengembangan tanaman Gonda menjadi produk wisata kuliner khas Desa Bongan dapat dikembangkan dengan tepat.

\section{KAJIAN TEORI}

Kajian mengenai factor penghambat dan pendukung pendayagunaan tanaman Gonda sebagai produk wisata kuliner khas Desa Bongan didasari oleh beberapa teori dan penelitian terdahulu yang memiliki focus yang sama. Beik (2016) dikutip dari Nurani (2019) mengemukakan lima hambatan yang ditemui oleh usaha skala kecil dan mikro dalam mengembangkan usaha, yaitu sebagai berikut.

a. Terbatasnya modal yang dimiliki pelaku usaha skala kecil dan mikro dalam mengembangkan usaha yang dimilikinya.

b. Kemampuan manajerial sumber daya manusia yang masih rendah dalam mengelola usaha sehingga mempengaruhi perkembangan usaha yang dimilikinya.

c. Kemampuan dalam melakukan pemasaran produk yang dikembangkan yang masih rendah sehingga produk tidak dikenal oleh yang public atau orang banyak.

d. Akses informasi usaha yang masih terbatas.

e. Hubungan antar pelaku usaha, baik itu sesama pelaku usaha skala kecil dan mikro, BUMN, maupun perusahan besar belum terjalin dengan baik.

Berdasarkan hal tersebut, Nurani (2019) melakukan kajian untuk menemukan factor penghambat pengembangan UMKM keripik pisang di Jalan AZ. Penelitian tersebut merupakan sebuah penelitian lapangan yang bersifat deskriptif analisis. Data diperoleh dengan melakukan wawancara, observasi, dan dokumentasi serta melibatkan 32 responden. Hasil analisis menunjukkan bahwa factor penghambat pengembangan UMKM Keripik Pisang di Jalan AZ adalah kemampuan sumber daya manusia atau pengelola yang terbatas dalam mengelola usaha, kurangnya penguasaan teknologi, belum menjalin kemitraan yang baik dengan pelaku usaha lainnya, modal yang masih terbatas, dan rendahnya inovasi dari pengelola. Faktor-faktor tersebut sejalan dengan yang dikemukakan oleh Beik (2016).

Penelitian sejenis juga dilakukan oleh Taib dan Roswita (2018) yang menganalisis prospek dan kendala pengembangan produksi pangan local di Sumatera Barat. Data dalam penelitian tersebut diperoleh dengan melakukan wawancara mendalam dan focus group discussion dengan pemilik industry pangan local. Hasil penelitian menunjukkan bahwa prospek pangan local adalah cita rasa yang menarik, keragaman produk yang dimiliki, pengembangan dapat dilakukan dalam skala kecil, serta dapat dimanfaatkan sebagai penunjang pariwisata. Di lain sisi, kendala yang dihadapi dalam pengembangan industry pangan local adalah kontinuitas bahan baku, kualitas sumber daya manusia atau tenaga kerja yang rendah, modal usaha yang terbatas, permasalahan dalam manajemen produksi, serta kurangnya pengawasan standar mutu.

Wayan Suteja (2019) melakukan penelitian mengenai Strategi Pengembangan Potensi Kuliner Lokal dalam Menunjang Kegiatan Pariwisata di Kawasan Ekonomi Khusus Mandalika Kabupaten Lombok Tengah. Penelitian ini bertujuan untuk mengetahui potensi dan strategi pengembangan potensi kuliner lokal dalam menunjang kegiatan pariwisata di KEK Mandalika. Penelitian menggunakan metode deskriptif kualitatif. Hasil penelitian menunjukan bahwa strategi pengembangan yang dapat dilakukan yaitu Strategi SO dengan inventarisasi dan programprogram yang menguatkan eksistensi kuliner lokal. Strategi WO dengan meningikatkan kelemahan yang dimiliki menjadi peluang dengan cara melatih masyarakat agar mampu mengkemas potensi wisata kuliner dan mengisi peluang usaha pariwisata. Strategi dengan memanfaatkan kekuatan untuk menangkal ancaman dengan cara optimalisasi peran masyarakat 
dalam pelestarian dan meningkatkan militansi terhadap budaya lokal. WT dengan mengubah kelemahan untuk menangkal ancaman dengan cara memperbanyak wawasan masyarakat dan pelaku wisatakuliner sehingga mampu melestarikan kuliner lokal dalam bentuk produk bernilai ekonomi. Penelitian ini mendukung karena sama-sama mengungkapkan keterlibatan peran kelompok atau warga dalam aktivitasnya, dan memaparkan lebih dalam terkait potensi kuliner lokal. Perbedaannya terletak pada lokasi penelitian.

Penelitian lain dilakukan oleh I Nyoman Tri Sutaguna dan Putra (2017), dengan judul Pengembangan Pengolahan Tape Sebagai Daya Tarik Wisata Kuliner Di Desa Wisata Bongkasa Pertiwi Abiansemal Badung. Tujuan penelitian ini untuk mengetahui bentuk-bentuk wisata kuliner apakah pada pengolahan tape di Desa Wisata Bongkasa Pertiwi yang dapat dikembangkan sebagai daya tarik wisata serta upaya apakah yang dilakukan untuk mengembangkannya. Penelitian merupakan penelitian deskriptif kualitatif. Hasil penelitian menunjukan bahwa bentukbentuk dari wisata kuliner pada pengolahan tape di Desa Wisata Bongkasa Pertiwi terdiri dari tape ketan manis, apem tape dan bolu tape. Semua jenis makanan tersebut setelah dianalisis berdasarkan kriteria keunikan, keragaman, kualitas produk, keterbatasan operasional, orijinalitas, dan tujuan finansial/ komersial memenuhi syarat untuk dikembangkan menjadi daya tarik wisata. Upaya-upaya yang dilakukan untuk mengembangkan wisata kuliner pada pengolahan tape di Desa Wisata Bongkasa Pertiwi sebagai salah satu daya tarik wisata meliputi persiapan bahan baku untuk proses pengolahan makanan, pengolahan bahan makanan yang siap untuk dimasak menjadi makanan yang siap untuk disantap atau dinikmati, dan upaya-upaya peningkatan penyajian makanan yang dimaksud agar lebih menarik. Penelitian ini dijadikan referensi karena serupa dengan penelitian penulis yang membahas mengenai produk wisata kuliner. Perbedaannya yaitu pada tujuan penelitian, dimana pada penelitian ini membahas khusus tentang bentuk-bentuk wisata kuliner pada pengolahan tape dan uapayanya untuk mengembangkan. Sedangkan peneliti sendiri lebih fokus kepada upaya mendayagunakan tanaman gonda agar dapat diproduksi dan dipasarkan sesuai standar produk yang ada.

\section{METODE PENELITIAN}

Penelitian ini menggunakan pendekatan deskriptif kualitatif yang bertujuan untuk menganalisis dan mengkaji factor penghambat dan pendukung pendayagunaan tanaman Gonda sebagai produk wisata kuliner khas Desa Bongan, Data yang digunakan dalam penelitian ini adalah data kualitatif yang berupa: a) data gambaran umum lokasi penelitian, b) data informasi kegiatan panen tanaman gonda, c) data area produksi teh dan keripik gonda, d) data hasil wawancara mengenai kegiatan pengolahan the dan keripik gonda.

Data diperoleh dari dua sumber data, yaitu sumber data primer dan sumber data sekunder. Data primer pada penelitian ini diperoleh dari hasil observasi baik itu pengamatan, pengukuran, dokumentasi langsung di lapangan dan data hasil wawancara dengan informan untuk mendapatkan informasi yang mendukung hasil penelitian meliputi berbagai hal yang berkaitan dengan pelaksanaan kegiatan panen madu. Informan yang diwawancarai yaitu: a) Warga yang (pernah) melakukan pengolahan teh dan keripik gonda, b) Petani/Pemilik area pertanian tanaman gonda, c) Pengurus Pokdarwis Dewi Manis, d) Masyarakat Bongan. Sedangkan sumber data sekunder dalam penelitian ini berupa dari studi pustaka, dokumen, artikel, dan jurnal.

Data dikumpulkan melalui tiga teknik, yaitu teknik observasi, wawancara, dan studi dokumentasi. Observasi langsung ini dilakukan peneliti untuk mengoptimalkan data mengenai pelaksanaan kegiatan pengolahan tanaman gonda, interaksi antara kelompok sadar wisata dengan petani setempat dan pemilik kebun, keadaan di lokasi panen, sarana dan prasarana yang 
digunakan, dan sebaginya. Teknik wawancara yang peneliti gunakan adalah secara terstruktur (tertulis) yaitu dengan menyusun terlebih dahulu beberapa pertanyaan yang akan disampaikan kepada informan. Penentuan informan pada penelitian ini dilakukan dengan teknik purposive sampling.

Penelitian ini menggunakan tiga teknik dalam menganalisa data yaitu:

1. Reduksi data: reduksi data dilakukan dengan meringkas data hasil wawancara dan observasi di lapangan

2. Analisa data: hasil reduksi data selanjutnya saling dikaitkan sesuai dengan landasan teori dan kajian pustaka yang digunakan.

3. Penarikan kesimpulan: peneliti dalam kaitan ini mempertajam kesimpulankesimpulan yang telah dibuat untuk sampai pada kesimpulan final.

\section{HASIL PENELITIAN DAN PEMBAHASAN}

Dari hasil pendataan di lapangan selama kegiatan penelitian dilakukan, ditemukan beberapa faktor yang kiranya dapat menghambat dan juga mendukung pendayagunaan tanaman gonda menjadi produk wisata Bongan berupa keripik dan teh gonda.

\section{Faktor Penghambat Pendayagunaan Keripik Gonda}

Berikut ini beberapa hal yang menghambat pendayagunaan tanaman gonda, sebagai berikut:

1. Keterbatasan kemampuan dalam melihat dan memanfaatkan kesempatan dan peluang yang ada dimulai dari lingkungan terdekat.

Desa Bongan merupakan penghasil tanaman (sayur) gonda yang berlimpah dan tidak mengenal musim serta cukup mudah dalam proses tanam dan panennya. Hal tersebut tidak serta merta membuat warga Bongan berusaha untuk melakukan pengolahan keripik ataupun teh seperti yang telah dilakukan oleh Mamak Ferlin dan Nengah Makir.

2. Pelaku usaha keripik dan teh gonda di Desa Bongan masing-masing hanya 1 orang Fenomena yang umum terlihat yaitu adanya kecenderungan masyarakat baru akan mulai merintis usaha yang sama bila sudah terdapat banyak orang yang menjalankan usaha tersebut atau terdapat satu atau beberapa orang yang bisa dikatakan sukses/berhasil dalam usaha tersebut. Kecenderungan tersebut berdasarkan pada asumsi bahwa sebuah usaha masal digandrungi untuk ditiru dikarenakan banyaknya kebutuhan di masyarakat atau dengan kata lain produknya dibutuhkan oleh banyak orang. Sedangkan untuk keripik gonda sendiri pelaku usahanya masih sangat terbatas di Bali, bahkan di Desa Bongan yang cukup luas hanya baru dilakoni oleh satu orang saja.

3. Kemampuan dan kemauan yang masih rendah

Kemampuan dan kemauan tidak dapat berjalan terpisah, saling terkait satu sama lain. Memiliki kemauan tanpa adanya kemampuan tidak cukup untuk modal merintis ataupun mengembangkan sebuah usaha. Begitu juga sebaliknya, memiliki kemampuan juga tidak cukup bila tidak disertai dengan adanya kemauan karena tidak akan menghasilkan perubahan apapun dalam pelaksanaannya. Hal ini belum terlihat pada warga Desa Bongan lainnya, hal tersebut yang menyebabkan hampir lima tahun ini usaha keripik gonda rintisan Mamak Ferlin tetap dilakoni tunggal. Sedangkan untuk teh gonda masih tetap dilakoni oleh Nengah Makir dengan konsumsi masih sebatas di lingkungan keluarga saja.

4. Hasil produksi keripik dan teh gonda masih perlu disempurnakan 
Terlihat dari kondisi produk yang rentan akan kandungan minyak berlebih, lebih lama didiamkan makin banyak minyak yang dihasilkan. Untuk itu perlu perbaikan dalam proses pengolahannya, baik dari resep maupun proses masaknya serta dukungan alat 'spinner' untuk hasil yang lebih optimal. Tujuannya kualitas produk 'keripik gonda' lebih maksimal dengan tekstur yang lebih baik dan lebih crispy, bebas minyak, serta rasa yang gurih menyesuaikan dengan cita rasa yang diinginkan, serta tahan lama. Sedangkan untuk teh gonda perlu dikaji kembali teknik pengolahan dengan menggunakan sinar matahari, apakah sudah efektif untuk diterapkan di dalam pengolahannya. Untuk tekstur dapat disesuaikan berdasar pada arahan dari pihak dinas kesehatan.

5. Kemasan yang masih sederhana

Selain tekstrur, cita rasa, dan ketahanan produk, hal yang perlu mendapat perhatian yaitu identitas produk. Identitas sangat penting dan menjadi hal penting ke dua selain kualitas. Identitas produk seperti logo, kemasan, dan story of product, diperlukan untuk memudahkan konsumen mengenali produk serta memudahkan dalam kegiatan pemasarannya.

6. Kebersihan dan kerapian sentra produksi

Perlu diberikan pengetahuan tentang standar hygiene \& sanitasi agar kualitas masingmasing produk terjamin kesehatannya saat dikonsumsi.

7. Belum memiliki hasil uji lab yang resmi untuk mengetahui khasiat dan manfaat dari tanaman gonda

Tanaman gonda sampai saat ini belum memiliki hasil uji lab untuk mengetahui manfaat yang terkandung di dalamnya. Bila kandungan telah diketahui pasti, akan mendukung kegiatan pemasaran dan memudahkan dalam menentukan target pasar dari masing-masing produk.

\section{Faktor Pendukung Pendayagunaan Keripik Gonda}

1. Tanaman gonda merupakan salah satu hasil bumi yang berlimpah yang dimiliki oleh Desa Bongan. Modal utama dalam produksi keripik dan teh gonda yaitu tanaman gonda, dimiliki hampir oleh sebagian besar masyarakat Desa Bongan. Hal ini sangat mendukung pendayagunaannya dikarenakan mudah diperoleh dan dengan biaya yang relatif murah.

2. Adanya tekad dan komitmen yang kuatMamak Ferlin yang sudah merintis usaha produksi keripik gonda selama empat tahun, pada tahun ketiga, pandemi Covid-19 mewabah tak terkendali yang menyebabkan kekacauan cukup mengkhawatirkan baik di bidang kesehatan dan juga perekonomian. Mamak Ferlin terpaksa merumahkan bertahap 3 orang karyawannya dan mencari pekerjaan lain selain membuat keripik, untuk dapat memenuhi kebutuhan keluarga. Hal tersebut tidak menyurutkan kemauan Mamak Ferlin, walaupun produksi menurun tetap mencari peluang pasar dan terus memproduksi keripik gonda walaupun dilakukan hanya sekitar 1-2 kali dalam seminggu. Bahkan Mamak Ferlin berinovasi dengan mengembangkan produk keripik dari sisi cita rasa. Sedangkan untuk teh gonda, Nengah Makir terus melakukan percobaan dan penyempurnaan dalam proses produksinya serta selalu mengkonsumsinya secara rutin bersama keluarga dan lingkungan terdekat yang mau mencoba.

3. Adanya peran serta pemerintah pusat dalam hal ini Kemenparekraf bekerjasama dengan institusi pendidikan, salah satu institusi yang berperan yaitu Kampus Politeknik Internasional Bali. Usaha keripik dan teh gonda Bongan, telah mendapat perhatian dan dukungan nyata dari PIB berupa pendampingan kegiatan PkM dengan 
melibatkan seluruh dosennya. Bergerak secara nyata dengan terlibat langsung dalam pendampingan, berupa pelatihan dan pengarahan untuk memaksimalkan sumber daya alam yang mereka miliki yaitu tanaman gonda. Dukungan nyata lainnya yaitu berupa pemberian peralatan dan perlengkapan yang dibutuhkan dalam pengolahan produksi keripik dan teh gonda.

\section{PENUTUP}

Pendayagunaan tanaman Gonda sebagai produk wisata kuliner khas Desa Bongan dipengaruhi oleh dua factor besar, yaitu factor penghambat dan factor pendukung. Keterbatasan jumlah masyarakat yang memberdayakan tanaman Gonda masih terbatas, keterbatasan kemampuan melihat peluang usaha, kemampuan dan kemauan yang masih rendah, hasil produksi keripik dan teh gonda masih perlu disempurnakan, kemasan yang masih sederhana, penataan ulang serta kebersihan dan kerapian area produksi, serta belum memiliki hasil uji lab yang resmi menjadi factor penghambat dalam mendayagunakan tanaman Gonda. Namun tidak hanya ditemukan factor penghambar, terdapat juga factor pendukung, yaitu melimpahnya hasil panen tanaman gonda yang tidak mengenal musim, adanya tekad dan komitmen yang kuat, dan adanya peran serta pemerintah pusat dalam hal ini Kemenparekraf bekerjasama dengan institusi pendidikan, salah satu institusi yang berperan yaitu Kampus Politeknik Internasional Bali. Faktor penghambat tersebut dapat diminimalkan dengan berbagai cara sehingga tidak menghambat pendayagunaan tanaman Gonda sebagai produk wisata kuliner khas Desa Bongan.

\section{DAFTAR RUJUKAN}

Nurani, M. (2019). Analisis factor-faktor penghambat pengembangan usaha mikro kecil dan menengah dalam perspektif ekonomi Islam. Lampung: Universitas Islam Negeri Raden Intan Lampung.

Sutaguna, I.N.T. \& Putra, A.M. (2019). Persepsi masyarakat Desa Panatahan terhadap dikembangkannya Desa Penatahan sebagai desa wisata di Kecamatan Penebel, Kabupaten Tabanan. Jurnal Perhotelan dan Pariwisata, Vol. 9(2).

Suteja, I.W. \& Wahyuningsih, S. (2019). Strategi pengembangan potensi kuliner local dalam menunjang kegiatan pariwisata di Kawasan ekonomi khusus Mandalika, Kabupaten Lombok Tengah. Media Bina Ilmiah, Vol. 14 (2).

Taib, G. \& Roswida, R. (2018). Analisis prospek dan kendala pengembangan produksi pangan lokal di Sumatera Barat. Jurnal Teknologi Pertanian Andalas, Vol. 22 (1). 